\title{
Efek Mediasi Perilaku Keuangan Terhadap Hubungan Antara Literasi Keuangan Dengan Keputusan Investasi
}

\author{
Perwito $^{1}$, Nugraha ${ }^{1}$, Sugiyanto ${ }^{2}$ \\ Universitas Pendidikan Indonesia ${ }^{1}$ \\ Institut Manajemen Koperasai Indonesia ${ }^{2}$ \\ perwitoe@upi.edu \\ Nugraha@upi.edu \\ ugie@ikopin.ac.id
}

\begin{abstract}
Abstrak
Hasil penelitian menunjukkan bahwa Literasi Keuangan (LK) berpengaruh positif terhadap Perilaku Keuangan (PK) dan Perilaku Keuangan memediasi secara penuh pengaruh Literasi Keuangan terhadap Keputusan Investasi. Pentingnya meningkatkan literasi keuangan (LK) khususnya pada Generasi Muda/mahasiswa sebagai agen perubahan harus memiliki sikap dan perilaku keuangan yang baik, pentingnya pengetahuan, keterampilan, dan keyakinan keuangan sejak dini, sehingga dikemudian hari dapat melakukan perencanaan dan tujuan keuangan, pengelolaan konsumsi, simpanan dan investasi, kredit, penganggaran, serta pengelolaan pajak penghasilan pribadi, yang muaranya dapat meningkatkan kesejahteraan keuangan (financial well being) hidupnya yang pada ahhirnya akan menjadi stimulus atau pendorong bagi kemajuan pembangunan ekonomi. Harapan selanjutnya, ada penelitian dengan peningkatan kompleksitas baik dari sisi variabel maupun cakupan sampel penelitian.
\end{abstract}

Kata kunci: Literasi keuangan, Perilaku Keuangan.

\begin{abstract}
The results showed that Financial Literacy had a positive effect on Financial Behavior and Financial Behavior mediated in full the influence of Financial Literacy on Investment Decisions. The importance of increasing financial literacy especially for the younger generation / students as agents of change must have good financial attitudes and behavior, the importance of financial knowledge, skills and confidence from an early age, so that in the future they can carry out financial planning and goals, managing consumption, savings and investment, credit, budgeting, and personal income tax management, which can improve the financial well being of his life which will eventually become a stimulus or a stimulus for the progress of economic development. The next hope is that there will be research with increasing complexity both in terms of variables and the scope of the research sample.
\end{abstract}

Keywords: Financial Literacy, Financial Behavior.

\section{PENDAHULUAN}

Perkembangan Financial Technology (Fintech) di Indonesia saat ini begitu pesat, data per 30 September 2019 yang terdaftar secara resmi sebanyak 127 perusahaan, (OJK, 2019). Pertumbuhan teknologi keuangan (fintech) saat ini menghadirkan dan merevolusi perilaku transaksi melakukan pembayaran ataupun dalam hal investasi keuangan. Investasi merupakan komitmen atas sejumlah dana atau sumber daya lainnya yang dilakukan saat ini, dengan tujuan untuk memperoleh imbal hasil (Return) dimasa yang akan datang (Tandelilin, 2010), investasi juga dimaknai sebagai pengorbanan sumber daya ekonomi dan sumber daya non ekonomi untuk memperoleh imbal hasil dikemudian hari (Perwito, 2011). Guna memperoleh return yang optimal, penting diperhatikan membuat keputusan investasi yang tepat sehingga risiko-risiko investasi dapat diminimalkan. Dalam konteks keuangan, Keputusan investasi merupakan serangkaian dalam mengorganisir aktivitas dalam proses investasi. Hal yang mendasar dalam keputusan investasi adalah pemahaman investor antara imbal hasil atau return dan risiko dari suatu investasi (Tandelilin, 2010), (Perwito, 2011).

Kesejahteraan dalam keuangan (financial weel being) dapat diciptakan melalui keputusan 
keuangan tepat. Seseorang yang berkomitmen dan melakukan keputusan keuangan jangka panjang khususnya investasi, penting perlunya membentuk lingkungan yang baik terkait sikap dan perilaku keuangannya. Perilaku keuangan yang baik akan meningkatkan kesejahteraan keuangan (Mokhtar \& Husniyah, 2017). (Gutter \& Copur, 2011). Secara keseluruhan, penelitian ini menemukan perilaku keuangan berhubungan positif dengan kesejahteraan keuangan, hal ini menunjukkan bahwa untuk menjadi sehat secara finansial, seseorang perlu menunjukkan perilaku yang diinginkan dengan manajemen kas dan kredit, menabung, investasi, dll. (Gumilar \& Aryati, 2020) (Fitriarianti, 2018) menemukan bahwa Perilaku keuangan (Financial behavior) berpengaruh positif dan signifikan terhadap keputusan investasi, semakin baik sikap atau perilaku keuangan seseorang maka dapat meningktkan dalam pengambilan keputusan investasi.

Literasi keuangan telah terlihat selama dua dekade terakhir dan beberapa negara maju seperti Amerika Serikat dan Inggris telah memperkenalkan program pendidikan keuangan di berbagai tingkatan. Negara-negara berkembang seperti Indoensia dengan pasar keuangan yang sedang tumbuh dapat belajar kesuksesan dan pelajaran yang mereka lakukan (Chu et al., 2016). Literasi keuangan menjadi perananan yang sangat penting dalam meningkatkan pengetahuan dan keterampilan sehingga mempengaruhi sikap dan perilaku dalam melakukan pengelolaan ataupun pengambilan keputusan keuangan baik dalam hal investasi ataupun pendanaan. Dalam konteks ini, penting untuk memahami seberapa pengetahuan masyarakat tentang keuangan mempengaruhi pengambilan keputusan keuangan ataupun pemanfaatan Fintech (Lusardi, 2019).

Indikator penting dari kemampuan orang untuk membuat keputusan keuangan adalah tingkat literasi keuangan atau Financial Literacy. Organisation for Economic Co-operation and Developmentatau (OECD, 2016) (SNLKI, 2017) menjelaskan literasi keuangan sebagai pengetahuan dan pemahaman atas konsep dan risiko keuangan, berikut keterampilan, motivasi, serta keyakinan untuk menerapkan pengetahuan dan pemahaman yang dimilikinya tersebut dalam rangka membuat keputusan keuangan yang efektif, meningkatkan kesejahteraan keuangan (financial well being) individu dan masyarakat, dan berpartisipasi dalam bidang ekonomi.

Melalui literasi keuangan diharapkan dapat mendukung upaya pencapaian pembangunan dalam sistem keuangan dan meningkatkan kesejahteraan masyarakat (Atkinson, 2011) (Lusardi, 2019) (Zulbetti et al., 2019). Bagi negara berkembang seperti Indonesia, tingkat literasi keuangan dapat dikatergorikan masih rendah, "Indeks Literasi Keuangan masyarakat Indonesia mengalami peningkatan dari $21,8 \%$ di tahun 2013 menjadi $29,7 \%$ di tahun 2016, yang bermakna dari setiap 100 penduduk hanya sekitar 30 orang yang termasuk kategori well literate. Adapun Terget prioritas literasi keuangan di Indonesia adalah diantaranya; pelajar/mahasiswa\&pemuda, karyawan, petani\&nelayan, TKI\& calon TKI, penyandang disabilitas, perempuan, dan UMKM (SNLKI, 2017).

Literasi keuangan memiliki pengaruh terhadap keputusan investasi, dengan memiliki tingkat literasi yang baik, maka perilaku ataupun keputusan investasi keuangannya juga semakin baik, hal ini sejalan dengan Hasil penelitian Samuel (2019), (Herawati, 2015) menyatakan bahwa Financial Litercay berpengaruh terhadap pengelolaan keuangan. Masyarakat dapat melakukan perencanaan keuangannya dengan baik, seperti pengelolaan konsumsi secara optimal, simpanan, dana pensiun agar memberikan manfaat dalam kelangsungan hidupnya (Lusardi \& Mitchell, 2007), (Lusardi, 2019), (OJK, 2019), (Hastings \& Mitchell, 2018) bahwa literasi keuangan berkorelasi dengan pengambilan keputusan investasi. Memberikan padangan cara membuat kebijakan keuangan individu yang lebih baik di mana individu melakukan pilihan tabungan dan investasi. Mahasiswa yang memiliki tingkat literesi keuangan yang baik, maka dalam membuat keputusan keuangannya relatif lebih baik apabila dibandingkan degan mahasiswa yang memiliki pengetahuan kurang (Ayu Krishna, Maya Sari, 2007). Semakin tinggi pengetahuan serta kemampuan mahasiswa dalam mengelola keuangan akan semakin bijak dalam pengambilan keputusan keuangan (Laily, 2016). Berbeda dari Budiarto (2017), (Putra et al., 2016), (Pradikasari \& Isbanah, 2018) bahwa Financial literacy tidak memiliki pengaruh terhadap keputusan investasi.

Literasi keuangan memiliki potensi untuk berkontribusi terhadap kesejahteraan finansial rumah tangga melalui investasi yang memberikan tingkat imbal hasil investasi yang positif, juga menemukan bahwa rumah tangga yang memiliki tingkat melek finansial yang tinggi lebih cenderung untuk berpartisipasi dalam pasar keuangan. Seseorang memiliki kecerdasan kecerdasan keuangan, semakin sedikit keberanian, rumah tangga yang memiliki tingkat melek finansial yang lebih tinggi lebih berhati-hati tentang investasi langsung (Chu et al., 2016).

Berdasarkan data dan permasalahan di atas, fokus kajian artikel ini adalah; 1) Pengaruh Literasi Keuangan terhadap Keputusan Investasi, 2) Pengaruh Literasi Keuangan terhadap Perilaku Keuangan, 3) Perilaku Keuangan terhadap 
Keputusan Investasi, 4) Efek Mediasi Perilaku Keuangan Terhadap Hubungan Antara Literasi Keuangan Dengan Keputusan Investasi.

\section{TINJAUAN PUSTAKA}

\section{a. Literasi Keuangan (Financial Literacy)}

Memiliki pengetahuan dan keyakinan pada lembaga, produk dan layanan jasa keuangan, serta keterampilan dalam mengelola keuangan akan menciptakan masyarakat yang lebih sejahtera dari aspek keuangan. (SNLKI, 2017) menyatakan seseorang dapat dikatakan sebagai well literate apabila memiliki pengetahuan dan keyakinan tentang lembaga, produk dan layanan jasa keuangan, serta keterampilan dalam mengetahui fitur, manfaat, risiko, hak dan kewajiban dari produk dan layanan jasa keuangan tersebut.

Organisation for Economic Co-operation and Developmentatau OECD (2016) mendefinisikan literasi keuangan sebagai pengetahuan dan pemahaman atas konsep dan risiko keuangan, berikut keterampilan, motivasi, serta keyakinan untuk menerapkan pengetahuan dan pemahaman yang dimilikinya tersebut dalam rangka membuat keputusan keuangan yang efektif, meningkatkan kesejahteraan keuangan (financial well being) individu dan masyarakat, dan berpartisipasi dalam bidang ekonomi.

Pengetahuan keuangan yang dimiliki oleh seseorang tersebut kemudian berkembang menjadi keterampilan keuangan, dimana keterampilan keuangan itu sendiri didefinisikan sebagai kemampuan dalam menerapkan pengetahuan keuangan yang dimilikinya dalam kehidupan sehari-hari (Palameta et.al, 2016). Keterampilan keuangan memungkinkan seseorang untuk dapat mengambil keputusan yang rasional dan efektif terkait dengan keuangan dan sumber ekonominya (Kurihara, 2013).

Carpena et.al (2011) menyatakan ada 3 (tiga) dimensi dari literasi keuangan yaitu (1) keterampilan menghitung, (2) pemahaman tentang keuangan dasar, dan (3) sikap terhadap keputusan keuangan. Sedangkan Willis (2008) menyatakan bahwa pengetahuan dalam konteks literasi keuangan meliputi pengetahuan, edukasi, dan informasi mengenai keuangan dan sumbernya, perbankan, deposito, kredit, asuransi, dan pajak.

Pengetahuan, keterampilan, dan keyakinan keuangan yang dimiliki oleh seorang individu berpengaruh terhadap sikap dan perilaku keuangannya. Peningkatan pengetahuan yang dimiliki seseorang dapat berdampak pada partisipasi yang aktif dalam kegiatan terkait keuangan, serta perilaku keuangan yang lebih positif pada seorang individu. Selain itu, kaitan antara perilaku dengan sikap seseorang terlihat pada seseorang yang memiliki sikap positif untuk jangka panjang kemungkinan besar akan menunjukkan perilaku keuangan yang lebih baik dibandingkan dengan seseorang yang memiliki sikap keuangan untuk jangka pendek (Atkinson \& Messy, 2012)

Masyarakat diharapkan dapat memiliki keyakinan terhadap lembaga jasa keuangan serta produk dan layanannya setelah memiliki pengetahuan dan keterampilan yang memadai. Tidak hanya terhadap industri jasa keuangan, keyakinan terhadap kemampuan juga harus dimiliki masing-masing individu. Keyakinan tersebut termasuk keyakinan dalam melaksanakan aktivitas keuangan seperti mencatat rencana investasi dan pengeluaran, menyusun rencana anggaran, dan sebagainya (Tustin, 2010).

Berdasarkan dari berbagai pendapat di atas, maka SNLKI 2017 menyemperunakan "Literasi keuangan merupakan pengetahuan, keterampilan, dan keyakinan yang mempengaruhi sikap dan perilaku untuk meningkatkan kualitas pengambilan keputusan dan pengelolaan keuangan dalam rangka mencapai kesejahteraan". Mengukur literasi keuangan meliputi Pengetahuan, keterampilan, dan keyakinan yang berkaitan dengan; Basic personal finance, Cash management, kredit, tabungan dan investasi, serta mengenai risiko.

\section{b. Perilaku Keuangan}

Aspek sikap dan perilaku keuangan juga menjadi perhatian dalam meningkatkan literasi keuangan. Sikap dan perilaku keuangan tersebut memberikan gambaran bahwa literasi keuangan bukan hanya semata-mata mengetahui, terampil dalam memanfaatkan, dan meyakini lembaga, produk dan layanan jasa keuangan, melainkan juga mengenai pentingnya perubahan sikap dan perilaku keuangan seseorang agar hidup lebih sejahtera (SNLKI 2017). Alasan yang mendasari perlunya aspek sikap dan perilaku keuangan dalam literasi keuangan adalah program literasi keuangan yang hanya mengandalkan pendekatan pengetahuan saja tidak dapat mengubah perilaku seseorang apabila mereka tidak memiliki sikap dan motivasi yang sesuai (World Bank, 2016).

Sementara itu, perilaku merupakan realisasi dari sikap. Sikap dan perilaku keuangan dimaksud dapat mendorong seseorang untuk; menentukan tujuan keuangan, memiliki 
perencanaan keuangan, mengambil keputusan keuangan, dan mengelola keuangan dengan lebih baik guna mencapai kesejahteraan. Selaras dengan strategi nasional OJK, maka sikap dan perilaku keuangan fokus pada; 1) tujuan dan perencanaan keuangan, kemampuan pengelolaan keuangan (SNLKI 2017).

\section{c. Keputusan Investasi Keuangan}

Keputusan melakukan investasi berarti seseorang menunda konsumsi atas dana yang dimiliki, harapannya dikemudian hari dapat melakukan konsumsi yang lebih besar atas dana yang diinvestasikannya. Investasi merupakan komitmen atas sejumlah dana atau sumber daya lainnya yang dilakukan saat ini, dengan tujuan untuk memperoleh imbal hasil (Return) dimasa yang akan datang (Tandelilin, 2010). Keputusan investasi merupakan kebijakan yang diambil atas dua atau lebih alternatif penanaman modal dengan harapan mendapatkan keuntungan dimasa yang akan datang.

Guna memperoleh return yang optimal, penting diperhatikan membuat keputusan investasi yang tepat sehingga risiko-risiko investasi dapat diminimalkan. Dalam konteks keuangan, Keputusan investasi merupakan serangkaian dalam mengorganisir aktivitas investasi atas penanaman modal yang memperhatikan tingkat risiko dengan harapan mendapatkan imbal dimasa yang akan datang (Tandelilin, 2010), (Jogiyanto, 2010), (Perwito, 2011). Proses Keputusan investasi Keuangan bisa berjalan baik manakala seseorang individu telah memiliki tujuan dan perencanaan keuangan, kemampuan pengelolaan keuangan (SNLKI, 2017).

\section{d. Model Penelitian}

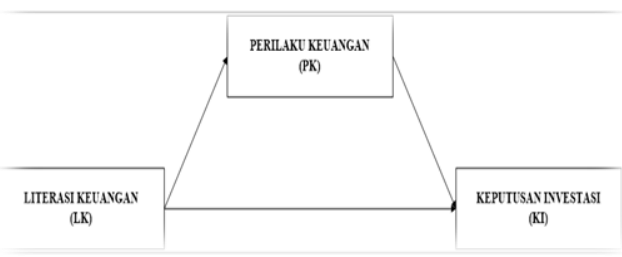

Gambar 1

Model Penelitian

Berdasarkan kerangka pemikiran di atas, maka hipotesis penelitian ini adalah:

H1 : Literasi Keuangan Berpengaruh Positif terhadap Keputusan

H2 : Literasi Keuangan Berpengaruh Positif terhadap Perilaku Keuangan
H3 : Perilku Keuangan Berpengaruh Positif Terhadap Keputusan Investasi

H4 : Perilaku Keuangan Memediasi penuh terhadap hubungan Literasi Keuangan dengan Keputusan Investasi

\section{METODE PENELITIAN}

Metode penelitian ini menggunakan pendekatan deskriptif verifikatif. Penelitian diskriptif dilakukan untuk mengetahui dan menjelaskan variabel yang diteliti. Sedangkan verifikatif bertujuan untuk menguji kausalitas hubungan antar variabel penelitian (Sekaran, 2006; Sugiyono, 2018). Dalam penelitian ini, Variabel bebas/Independent Variable adalah Literasi keuangan (Financial Literacy), pertanyaan berkaitan dengan literasi keuangan mengadopsi dari (Lusardi et al., 2010), (Clark et al., 2017), (Atkinson \& Messy, 2012) berkaitan dengan; konsep keuangan dasar seperti time value of money tingkat bunga tabungan dan bunga majemuk; pemahaman tentang inflasi; pajak penghasilan pribadi. Adapun Variabel terikat/dependet variable yakni Perilaku Keuangan, indikator instrumen pertanyaan berkaitan dengan; tujuan dan perencanaan keuangan, kemampuan pengelolaan keuangan (SNLKI, 2017). Sedangkan keputusan investasi diukur menggunakan; risiko (risk), imbal hasil (return), dan diversifikasi risiko (Tendelilin, 2010), (Atkinson \& Messy, 2012), (Lusardi \& Mitchell, 2014).

Populasi dalam penelitian ini mahasiswa aktif Fakultas Ekonomi dan Bisnis pada Politeknik Piksi Ganseha. Teknik sampling menggunakan purposive sampling yakni sebanyak 93 mahasiswa dengan kriteria yang telah mengambil mata kuliah manajemen keuangan serta pernah mengikuti pelatihan pasar modal yang diselenggarakan Oleh Galeri Investasi Politeknik Piksi Ganesha.

Sumber data utama dalam penelitian diperoleh dari kuesioner yang dilakukan pada bulan Maret-April 2020 dengan skala likert (5-4-3-2-1). Adapun data sekunder yang digunakan dalam penelitian seperti; studi literatur, artikel/jurnal ilmiah, dan data publikasi yang relevan dalam penelitiaan ini. Teknik Analisis data meliputi; uji validitas dan reliabilitas instrumen penelitian, untuk menguji hipotesis efek mediasi menggunakan teknik Bootstrapping approach, bantuan SPSS 25, dan PROCESS Version 3.4.

\section{HASIL DAN PEMBAHASAN}

\section{A. Hasil Analisis Deskreptif Variabel Literasi Keuangan, Perilaku Keuangan, dan Keputusan Investasi}

Hasil analisis Deskripsi variabel literasi keuangan, Perilaku keuangan, dan keputusan investasi adalah sebagai berikut: 
Tabel 1. Hasil Analisis Statistik Deskreptif

\begin{tabular}{|c|c|c|c|c|c|c|}
\hline No & Dimensi & Skor & $\begin{array}{l}\text { Skor } \\
\text { Mak }\end{array}$ & $\begin{array}{l}\text { Skor } \\
\text { Min }\end{array}$ & $\%$ & Katagori \\
\hline \multicolumn{7}{|c|}{ Literasi Keuangan } \\
\hline 1 & $\begin{array}{l}\text { Pemahaman time value } \\
\text { of money (bunga } \\
\text { tabungan dan bunga } \\
\text { majemuk) }\end{array}$ & 731 & 1.116 & 279 & 65,50 & $\begin{array}{l}\text { Sufficient } \\
\text { literate }\end{array}$ \\
\hline 2 & Pemahaman inflasi & 712 & 1.116 & 279 & 63,80 & $\begin{array}{c}\text { Sufficient } \\
\text { literate }\end{array}$ \\
\hline 3 & $\begin{array}{l}\text { Pemahaman pajak } \\
\text { penghasilan pribadi }\end{array}$ & 701 & 1.116 & 279 & 62,81 & $\begin{array}{l}\text { Sufficient } \\
\text { literate }\end{array}$ \\
\hline & Jumlah & 2.144 & 3.348 & 837 & 64,04 & $\begin{array}{l}\text { Sufficient } \\
\text { literate }\end{array}$ \\
\hline \multicolumn{7}{|c|}{ Perilaku Keuangan } \\
\hline 1 & $\begin{array}{l}\text { Tujuan dan perencanaan } \\
\text { keuangan }\end{array}$ & $\begin{array}{c}1.09 \\
3\end{array}$ & 1.860 & 372 & 58,76 & Kurang Baik \\
\hline 2 & $\begin{array}{l}\text { Kemampuan } \\
\text { pengelolaan keuangan }\end{array}$ & $\begin{array}{c}1.05 \\
4\end{array}$ & 1.860 & 372 & 56,67 & Kurang Baik \\
\hline & Jumlah & $\begin{array}{c}2.14 \\
7\end{array}$ & 3.720 & 744 & 57,72 & Kurang Baik \\
\hline \multicolumn{7}{|c|}{ Keputusan Investasi } \\
\hline & Risiko (Risk) & 848 & 1.395 & 279 & 60,79 & Kurang Baik \\
\hline & Imbal Hasil (Return) & 827 & 1.395 & 279 & 59,28 & Kurang Baik \\
\hline & Diversifikasi Risiko & 780 & 1.395 & 279 & 55,91 & Kurang Baik \\
\hline & Jumlah & 2.455 & 4.185 & 837 & 58,66 & Kurang Baik \\
\hline
\end{tabular}

(Sumber: Hasil Pengolahan Data 2020)

Berdasarkan Tabel 1 dapat dijelaskan bahwa; variabel Literasi Keuangan (Financial Literacy) dikembangkan dengan 3 indikator dan 9 item instrumen pernyataan, diperoleh rata-rata skor pencapaian sebesar $64,04 \%$ dan pada pada kategori Sufficient literate, yang bermakna bahwa responden memiliki pengetahuan dan keyakinan tentang lembaga jasa keuangan serta produk dan jasa keuangan, termasuk fitur, manfaat dan risiko, hak dan kewajiban terkait produk dan jasa keuangan kurang baik (OECD, 2018) (Zulbetti et al., 2019).

Variabel Perilaku Keuangan dengan 2 indikator dan 8 item instrumen pernyataan, diperoleh rata-rata skor pencapaian sebesar 57,72\% dan pada Kurang Baik, Variabel keputusan investasi dikembangkan dengan 3 indikator dan 9 item instrumen pernyataan, diperoleh rata-rata skor pencapaian sebesar 58,66\% dan pada pada kategori kurang baik.

\section{B. Hasil Pengujian Hipotesis Statistik}

Untuk mengetahui efek mediasi dalam penelitian ini menggunakan Bootstrapping approach, dengan alasan sebagai berikut: 1) dapat digunakan untuk menguji efek mediasi paralel maupun serial dengan jumlah variabel mediator lebih dari dua, 2) Tidak mensyaratkan koefisien $a$ dan $b$ berdistribusi normal. (Rungtusanatham, Miller \& Boyer, 2014; Turnes \& Ernst, 2015; dalam Kusnendi, 2019), hasil analisis adalah sebagai berikut:

1) Pengaruh Literasi Keuangan (LK) Terhadap Perilaku Keuangan (PK)

Tabel 2. Pengaruh LK terhadap PK (Model 1)

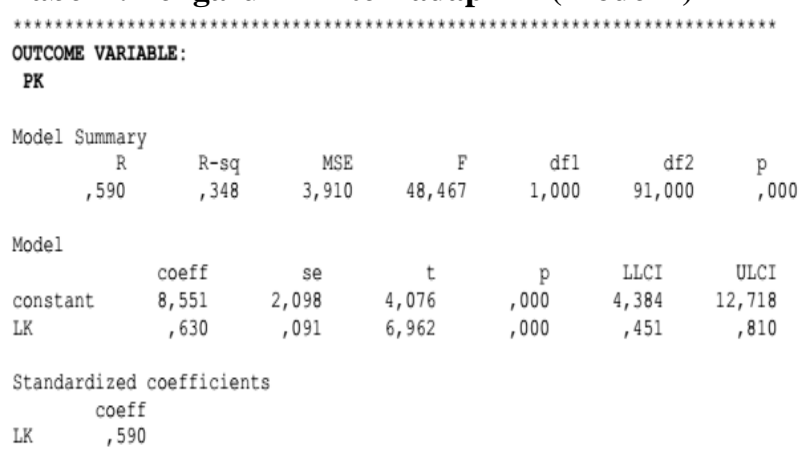

Berdasarkan hasil pengujian pada tabel 2 dapat dijelaskan bahwa; Koefisien regresi $a=0.630, \mathrm{t}=$ 6.962, $p-0.000<0.05$. $\mathrm{PK}=8.551+0.630 * * * \mathrm{LK}+$ $\mathrm{e}_{1}$. Hasil uji signifikan yang barmakna bahwa Literasi Keuangan (LK) berpengaruh positif terhadap Perilaku Keuangan (PK). 


\section{2) Pengaruh Perilaku Keuangan Terhadap Keputusan Investasi}

Tabel 3. Pengaruh KPK, LK terhadap KI

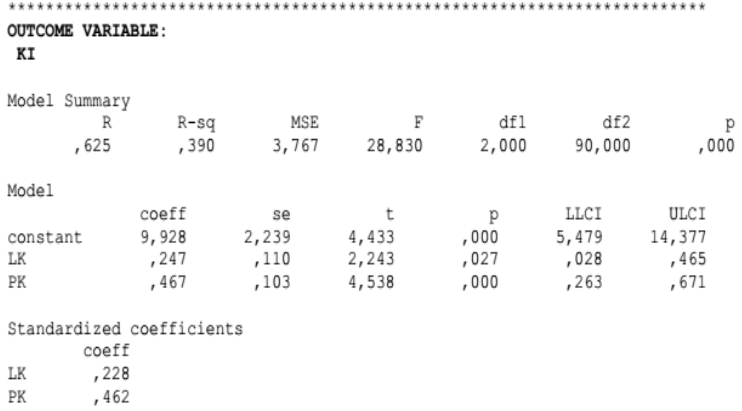

Berdasarkan hasil pengujian pada tabel 3 dapat dijelaskan bahwa; Koefisien regresi $a=0.247, \mathrm{t}=$ 2.243, $p-0.27<0.05, \mathrm{KI}=9.928+0.247 * * * \mathrm{LK}+\mathrm{e}_{1}$. Hasil uji signifikan, yang barmakna bahwa Literasi Keuangan (LK) berpengaruh positif terhadap Keputusan Investasi (KI).

Sedangkan Koefisien regresi $a=0.467, \mathrm{t}=4.538$, $p-0.000<0.05, \quad \mathrm{KI}=9.928+0.467 * * * \mathrm{PK}+\mathrm{e}_{1}$. Hasil uji signifikan, yang barmakna bahwa Perilaku Keuangan (PK) berpengaruh positif terhadap Keputusan Investasi (KI).

\section{3) Ringkasan Hasil Pengaruh Total, Langsung dan Tidak Langsung}

Tabel 4. Ringkasan Hasil Pengaruh Total, Langsung dan Tidak Langsung Pengaruh LK Terhadap KI dengan Mediasi PK

\begin{tabular}{ccccccc}
\hline Pengaruh & $\begin{array}{c}\text { Statist } \\
\text { ik }\end{array}$ & t-statistik & $\begin{array}{c}\text { Nilai } \\
\boldsymbol{p}\end{array}$ & $\begin{array}{c}\text { Boot } \\
\text { LLCI }\end{array}$ & $\begin{array}{c}\text { Boot } \\
\text { ULCI }\end{array}$ & $\begin{array}{c}\text { Hasil } \\
\text { Uji }\end{array}$ \\
\hline Total & 0,541 & 5.523 &, 000 & & & Signifikan \\
Langsung & 0,247 & 2.243 &, 027 & & & Signifikan \\
Tidak Langsung & 0,294 & - & $<0,05$ & 0,054 & 0,183 & Signifikan \\
\hline
\end{tabular}

(Sumber: Hasil Pengolahan Data 2020)
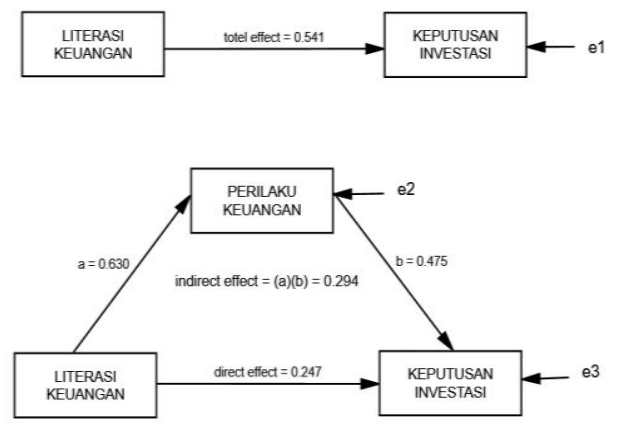

Gambar 2 : Model Empirik Penelitiaan

Berdasarkan hasil pengujian pada tabel 4 gambar 2 dapat dijelaskan bahwa;
1) Total pengaruh (effect) LK terhadap KI signifikan $(\mathrm{c}=0.541, \mathrm{t}=5.523, p-0.000<$ $0.05)$.

2) Direct effect LK terhadap KI signifikan ( $\mathrm{c}^{\prime}=$ $0.247, \mathrm{t}=2.243, \mathrm{p}=0.027<0.05$ )

3) Indirect effect $\mathrm{LK}$ terhadap $\mathrm{KI}$ melalui $\mathrm{PK}=\mathrm{a} \cdot \mathrm{b}$ $=(0.630)(0.467)=0.294$. Hasil uji bootstrapping $=(95 \%$ CI $[0.054,0.183])$. Pada interval kepercayaan 95\% estimasi koefisien indirect effect LK terhadap KI melalui PK berkisar antara 0.054 sampai 0.183 . Hasil estimasi tidak memberikan angka nol yang bermakna bahwa Hasil uji signifikan. $\mathrm{H}_{1}$ diterima dan dengan tingkat kesalahan $(p) 0,05$, maka dapat disimpulkan Perilaku Keuangan (PK) memediasi secara penuh pengaruh Literasi Keuangan (LK) terhadap Keputusan Investasi (KI).

\section{Pembahasan}

\section{Literasi Keuangan terhadap Perilaku keuangan}

Hasil analisis data menunjukkan bahwa literasi Keuangan pada kategori pada kategori Sufficient literate. Orang yang melek keuangan akan memiliki pengetahuan dasar tentang konsep dasar. Literasi keuangan yang bermakna bahwa responden memiliki pengetahuan, keterampilan, dan keyakinan tentang lembaga jasa keuangan serta produk dan jasa keuangan, termasuk fitur, manfaat dan risiko, hak dan kewajiban terkait produk dan jasa keuangan kurang baik. Hal ini ditengarai masyarakat Indonesia belum sepenuhnya memiliki pengetahuan yang cukup mengenai bagaimana mengoptimalkan uang atau danaya untuk kegiatan yang produktif. Di samping itu, masyarakat juga belum memahami dengan baik berbagai produk dan layanan jasa keuangan yang ditawarkan oleh lembaga jasa keuangan formal seperti; produk Perbankan, perasuransian, pembaga pembiayaan, dana pensiun, pengadaian, pasar modal, bahkan masyarakat kita lebih tertarik pada tawaran-tawaran investasi lain yang berpotensi merugikan mereka (OJK, 2017) dan pentingnya peran dari pemerintah dalam membuat kebijakkan yang mendukung tinkat literasi masyarakat (Grohmann et al., 2018).

Hasil analisis menunjukkan bahwa Literasi keuangan berpengaruh positif dan signifikan terhadap perilaku keuangan sebesar $(0.630 * 0.630=39,69 \%)$, pengetahuan, keterampilan, dan keyakinan sesorang akan membawa perubahan pada sikap dan perilaku keuangannya, seseorang dapat melakukan perencanaan dan tujuan keuangan, mengatur keuangan khususnya berkaitan dengan tingakt bunga simpanan dan investasi. (Courchane \& Zorn, 2005) (Taft et al., 2013) menemukan bahwa pengetahuan keuangan berdampak langsung pada seseorang berperilaku dalam pengelolaan 
tabungan, penganggaran, pengeluaran, serta kredit yang lebih baik. (Atkinson \& Messy, 2012) (Atkinson et al., 2015) Cara seseorang berperilaku akan memiliki dampak signifikan pada kesejahteraan keuangan mereka, penting untuk meningkatkan perilaku keuangan melalui literasi keuangan,. Pengetahuan, keterampilan, dan keyakinan keuangan yang dimiliki oleh seorang individu akan memepengaruhi sikap dan perilaku keuangannya. (Anita, 2015) bahawa literasi keuangan memiliki pengaruh positif terhadap perilaku keuangan.

Hasil penelitian (Clark et al., 2017) menemukan bahwa literasi keuangan mempengaruhi perilaku karyawan dalam membuat perencanaan tabungan pensiun, karyawan yang memilki pengetahuan keuangan yang baik lebih cenderung untuk berpartisipasi dalam program pensiun mereka, berkontribusi lebih tinggi atau mengalokasikan lebih gaji mereka untuk dana pensiun, dan memiliki lebih banyak tabungan. Secara umum, tingkat melek literasi keuangan yang lebih baik, akan memiliki kesiapan pensiun yang lebih baik pula. Pemahaman yang lebih baik tentang perilaku keuangan karyawan, yang dapat ditingkatkan melalui pendidikan keuangan di tempat kerja (Mokhtar \& Husniyah, 2017).

(Herawati, 2015) bahwa literasi keuangan memiliki kontribusi yang positif dan signifikan terhadap perilaku keuangan mahasiswa, dengan demikian baik tidaknya perilaku keuangan mahasiswa dapat dijelaskan oleh literasi keuangan. Meningkatnya indeks literasi keuangan, maka diharapakan perilaku untuk melakukan investasi keuangan juga semakin baik. Hal ini selaras dengan hasil penelitian (Rasuma Putri \& Rahyuda, 2017), (Angga Budiarto, 2017) (Laily, 2016) bahwa literasi keuangan literasi keuangan memiliki pengaruh yang signifikan terhadap perilaku keuangan mahasiswa.

Seiring dengan peningkatan indeks literasi keuangan diharapkan akan mengubah perilaku keuangan, sikap keuangan, serta pengetahuan. Setiap individu dan khususnya Mahasiswa jadi lebih melek terhadap produk dan jasa keuangan. Peran perguruan tinggi dalam menigkatkan literasi keuangan sangat diharapkan, mahasiswa sebagai generasi penerus bangsa harus memiliki pengetahuan tentang keuangan yang baik, sehingga menjadi pribadi yang cerdas mengatur keuangan dan memiliki kehidupan yang lebih sejahtera (Margaretha \& Pambudhi, 2015).

Dalam penelitian ini aspek pajak penghasilan pribadi dimasukan dalam unsur literasi keuangan, setelah selesai kuliah hampir sebagian besar mencari kerja dan jadi karyawan. Saat menjadi karyawan diharapkan memiliki sikap dan perilaku yang lebih baik, mereka setiap bulan akan mendapatkan penghasilan berupa gaji, sehingga mereka bisa melakukan perhitungan $\mathrm{PPh}$ pribadi, melaporkan, dan membayar pajak, ini sebagai salah satu sumbangsih kepada negara.

\section{Literasi Keuangan terhadap Keputusan Investasi}

Tingkat melek keuangan di Indonesia masih sangat rendah, Indeks Literasi Keuangan masyarakat Indonesia pada tahun 2016 sebesar 29,7\%, ini menunjukkan dari 100 orang, sebesar $30 \%$ yang sudah melek keuangan (SNLKI, 2017). Belum melek keuangan tampaknya bertahan untuk waktu yang lama, khususnya di daerah pedesaan atau tertinggal. Mengingat hubungan yang kuat antara literasi keuangan dengan keputusan investasi, penting untuk menumbuhkan pengetahuan, keterampilan, dan keyakinan keuangan. Masyarakat dapat melakukan perencanaan keuangannya dengan baik, seperti pengelolaan konsumsi secara optimal, simpanan, dana pensiun agar memberikan manfaat dalam kelangsungan hidupnya (Lusardi \& Mitchell, 2007), (Lusardi, 2019), (OJK, 2019).

(Hastings \& Mitchell, 2018) bahwa literasi keuangan berkorelasi dengan pengambilan keputusan investasi. memberikan padangan cara membuat kebijakan keuangan individu yang lebih baik di mana individu melakukan pilihan tabungan dan investasi. Khusunya bagi yang memiliki pendidikan kurang, serta untuk memfasilitasi orang yang berkomitmen dan melakukan keputusan keuangan jangka panjang. Pengetahuan, keterampilan, dan keyakinan keuangan yang dimiliki oleh seorang individu berpengaruh terhadap sikap dan perilaku keuangannya yang pada akhirnya saat membuat keputusan investasi keuangannya semakin baik. Mahasiswa yang memiliki tingkat literesi keuangan yang baik, maka dalam membuat keputusan keuangannya relatif lebih baik apabila dibandingkan degan mahasiswa yang memiliki pengetahuan kurang (Ayu Krishna, Maya Sari, 2007). Semakin tinggi pengetahuan serta kemampuan mahasiswa dalam mengelola keuangan akan semakin bijak dalam pengambilan keputusan keuangan (Laily, 2016). (Welly et al., 2012) menemukan bahwa literasi keuangan (pengetahuan umum keuangan pribadi, simpanan dan pinjaman, asuransi, dan investasi memberikan pengaruh signifikan terhadap keputusan investasi dosen, karyawan, dan mahasiswa. Berbeda dari (Pradikasari \& Isbanah, 2018) bahwa Financial literacy tidak memiliki pengaruh terhadap keputusan investasi pada mahasiswa di Kota Surabaya.

(Williamson, 1998) menemukan bahwa peserta dengan pengetahuan yang kurang cenderung 
memiliki pendapat yang salah dan membuat keputusan yang salah dalam bidang pengetahuan umum, tabungan dan pinjaman serta investasi. Meningkatkan kemampuan dan pengetahuan keuangan pribadi menjadi hal yang penting, tanpa pengetahuan yang memadai, mereka lebih cenderung membuat keputusan yang salah. Ketidakmampuan akan membatasi kemampuan mereka untuk membuat keputusan keuangan yang tepat. Literasi keuangan memiliki potensi untuk berkontribusi terhadap kesejahteraan finansial rumah tangga melalui investasi yang memberikan tingkat imbal hasil investasi yang positif, juga menemukan bahwa rumah tangga yang memiliki tingkat melek finansial yang tinggi lebih cenderung untuk berpartisipasi dalam pasar keuangan. Seseorang memiliki kecerdasan kecerdasan keuangan, semakin sedikit keberanian, rumah tangga yang memiliki tingkat melek finansial yang lebih tinggi lebih berhati-hati tentang investasi langsung (Chu et al., 2016).

Masyarakat yang well literate lebih mudah memahami hal-hal yang terkait dengan industri jasa keuangan serta memiliki informasi untuk mengakses industri jasa keuangan yang diperlukan dalam aktivitas kehidupan sehari-hari mereka. Hal tersebut memungkinkan mereka lebih mudah dalam menentukan produk dan layanan jasa keuangan yang sesuai dengan kebutuhan dan kemampuan dalam upaya meningkatkan kesejahteraan mereka dan pada akhirnya akan mendukung pembangunan ekonomi (OJK, 2017). Literasi keuangan telah terlihat selama dua dekade terakhir dan beberapa negara maju seperti Amerika Serikat dan Inggris telah memperkenalkan program pendidikan keuangan di berbagai tingkatan. Negara-negara berkembang seperti Indoensia dengan pasar keuangan yang sedang tumbuh dapat belajar kesuksesan dan pelajaran yang mereka lakukan (Chu et al., 2016).

\section{Perilaku Keuangan terhadap Keputusan Investasi}

Masyarakat yang memiliki dan mampu memenuhi kewajiban keuangan saat ini maupun di masa yang akan datang menjadi harapan kita semua, memiliki tingkat persiapan yang baik untuk pemenuhan kebutuhan keuangan di masa depan, dan mampu membuat keputusan dalam menentukan pilihan yang dapat dinikmati dalam hidupnya baik untuk saat ini atau masa depan (SNLKI, 2017).

Kesejahteraan keuangan dapat ditingkatkan melalui investasi, investasi merupakan pengorbanan sumber daya ekonomi dan sumber daya lainnya untuk mendapatkan imbal hasil dimasa yang akan datang. Seseorang yang berkomitmen dan melakukan keputusan keuangan jangka panjang khususnya investasi, penting perlunya membentuk lingkungan yang baik terkait sikap dan perilaku keuangannya. Hasil analisis menunjukkan bahwa perilaku keuangan memediasi secara penuh terhadap hubungan antara literasi keuangan dengan keputusan investasi.

Perilaku keuangan yang baik akan meningkatkan kesejahteraan keuangan karyawan (Mokhtar \& Husniyah, 2017). (Gutter \& Copur, 2011) Secara keseluruhan, penelitian ini menemukan perilaku keuangan berhubungan positif dengan kesejahteraan keuangan, dengan pengecualian penganggaran. Hal ini menunjukkan bahwa untuk menjadi sehat secara finansial, seseorang perlu menunjukkan perilaku yang diinginkan dengan manajemen kas dan kredit, menabung, investasi, dll. (Gumilar \& Aryati, 2020) (Fitriarianti, 2018) menemukan bahwa Perilaku keuagnan (Financial behavior) berpengaruh positif dan signifikan terhadap keputusan investasi, semakin baik sikap atau perilaku keuangan seseorang maka dapat meningktkan dalam pengambilan keputusan investasi. (Herdjiono et al., 2016) bahwa sikap keuangan seseorang akan cenderung memiliki perilaku keuangan yang lebih bijak.

\section{SIMPULAN DAN SARAN}

Berdasarkan pembahasan di atas, kesimpulan dalam artikel ini; Literasi keuangan berpengaruh positif terhadap Perilaku keuangan. Literasi keuangan berpengaruh positif baik langsung maupun tidak langsung terhadap keputusan investasi melalui Perilaku keuangan, dapat dimaknai bahwa perilaku keuangan memediasi secara penuh terhadap hubungan antara Literasi keuangan dengan Keputusan investasi.

Generasi Muda/mahasiswa sebagai agen perubahan harus memiliki sikap dan perilaku keuangan yang baik, pentingnya pengetahuan, keterampilan, dan keyakinan keuangan sejak dini, sehingga dikemudian hari dapat melakukan perencanaan dan tujuan keuangan, pengelolaan konsumsi, simpanan dan investasi, kredit, penganggaran, serta pengelolaan pajak penghasilan pribadi, yang muaranya dapat meningkatkan kesejahteraan keuangan (financial well being).

Saran penelitian ini adalah; Perlu adanya Penelitian secara mendalam berkaitan dengan perilaku keuangan, proses pengambilan keputusan investasi, dan kususnya kajian berkaitan dengan diversifikasi investasi. Selain itu harapan selanjutnya, ada penelitian dengan peningkatan kompleksitas baik dari sisi variabel maupun cakupan sampel penelitian. Ucapan terima kasih dan penghargaan yang setinggi-tingginya kepada Dosen pengampu mata kuliah dan teman-teman mahassiswa Progam Doktor Manajemen Sekolah Pascasarjana Universitas Pendidikan Indonesia. 


\section{DAFTAR PUSTAKA}

Angga Budiarto, S. (2017). Pengaruh Financial Literacy, Overconfidence, Regret Aversion Bias, Dan Risk Tolerance Terhadap Keputusan Investasi (Studi pada investor PT. Sucorinvest Central Gani Galeri Investasi BEI Universitas Negeri Surabaya). 05, 1-9.

Anita, S. D. (2015). Financial Literacy dan perilaku keuangan mahasiswa. Buletin Bisnis \& Manajemen, 01(02), 171-189.

Atkinson, A. (2011). Finance: Assessing financial literacy in 12 countries: an OECD / INFE Assessing financial literacy in 12 countries : an OECD / INFE international pilot exercise *. 657-665.

https://doi.org/10.1017/S1474747211000539

Atkinson, A., \& Messy, F.-A. (2012). Measuring Financial Literacy: Results of the Oecd Infe Pilot Study. Oecd, 15, 1-73. https://doi.org/https://doi.org/10.1787/bb2cd70 c-en

Atkinson, A., Messy, F., Rabinovich, L., \& Yoong, J. (2015). Financial Education for Long-term Savings and Investments. OECD Working Papers on Finance, Insurance and Private Pensions, OECD Publi(39), 1-33. https://doi.org/10.1787/5jrtgzfl6g9w-en

Ayu Krishna, Maya Sari, R. R. (2007). Analisis Tingkat Literasi Keuangan Di Kalangan Mahasiswa dan Faktor-Faktor yang Mempengaruhinya ( Survey Pada Mahasiswa Universitas Pendidikan Indonesia ). 1-6.

Chu, Z., Wang, Z., Xiao, J. J., \& Zhang, W. (2016). Financial Literacy, Portfolio Choice and Financial. Social Indicators Research. https://doi.org/10.1007/s11205-016-1309-2

Clark, R., Lusardi, A., \& Mitchell, O. S. (2017). Employee Financial Literacy and Retirement Plan Behavior: a Case Study. Economic Inquiry, 55(1), 248-259. https://doi.org/10.1111/ecin.12389

Courchane, M., \& Zorn, P. (2005). Consumer literacy and credit worthiness. and Pitfalls: As Consumer Options Multiply, Who Is ..., February 2005, 1-33. http://www.wdfi.org/_resources/indexed/site/y $\mathrm{mm} /$ govcouncilfinlit/presentations/ConsumerLi teracyCreditWorthinessWI-DataWIDFI.pdf

Fitriarianti, B. (2018). Pengaruh Literasi Keuangan, Perilaku Keuangan Dan Pendapatan Terhadap Keputusan Berinvestasi. Proseding Seminar Nasional Akuntansi.
Grohmann, A., Klühs, T., \& Menkhoff, L. (2018). Does financial literacy improve financial inclusion? Cross country evidence. World Development, 111, 84-96. https://doi.org/10.1016/j.worlddev.2018.06.020

Gumilar, A., \& Aryati, I. (2020). Financial Literacy , Financial Attitude dan Financial Behavior Terhadap Keputusan Investasi Saham ( Studi Kasus Investor pasar modal Surakarta ). 386390.

Gutter, M., \& Copur, Z. (2011). Financial Behaviors and Financial Well-Being of College Students: Evidence from a National Survey. 699-714. https://doi.org/10.1007/s10834-0119255-2

Hastings, J., \& Mitchell, O. S. (2018). How financial literacy and impatience shape retirement wealth and investment behaviors. Journal of Pension Economics and Finance, 19(1), $1-20$. https://doi.org/10.1017/S1474747218000227

Herawati, N. T. (2015). Kontribusi pembelajaran di perguruan tinggi dan literasi keuangan terhadap perilaku keuangan mahasiswa. 6070.

Herdjiono, I., Damanik, L. A., \& Musamus, U. (2016). Pengaruh Financial Atti Tude, Financial Knowledge, Parental Income Terhadap Financial Management Behavior. Manajemen Teori Dan Terapan, 1(3), 226241.

Jogiyanto. H. 2009. Teori Portofolio dan Analisis Investasi. Edisi ke enam. Yogyakarta: BPFE

Kusnendi. 2019. Materi Bahan Ajar. Sekolah Pascasarjana Universitas Pendidikan Indonesia.

Laily, N. (2016). Pengaruh Literasi Keuangan Terhadap Perilaku Mahasiswa Dalam Mengelola Keuangan. Journal of Accounting and Business Education, 1(4). https://doi.org/10.26675/jabe.v1i4.6042

Lusardi, A. (2019). Financial literacy and the need for financial education: evidence and implications. Swiss Journal of Economics and Statistics, 155(1), 1-8. https://doi.org/10.1186/s41937-019-0027-5

Lusardi, A., \& Mitchell, O. S. (2007). Baby Boomer retirement security: The roles of planning, financial literacy, and housing wealth \$. 54, 205-224.

https://doi.org/10.1016/j.jmoneco.2006.12.001 
Lusardi, A., \& Mitchell, O. S. (2014). The economic importance of financial literacy: Theory and evidence. Journal of Economic Literature, 52(1), 5-44. https://doi.org/10.1257/jel.52.1.5

Lusardi, A., Mitchell, O. S., \& Curto, V. (2010). The Journal of Consumer Affairs. The Journal of Consumer Affairs, Vol. 44(No. 2), 22. http://www.councilforeconed.org/wp/wpcontent/uploads/2011/11/Financial-Literacyfor-Young-Lusardi.pdf

Margaretha, F., \& Pambudhi, R. A. (2015). Tingkat Literasi Keuangan Pada Mahasiswa S-1. 17(1), 76-85. https://doi.org/10.9744/jmk.17.1.76

Mokhtar, N., \& Husniyah, A. R. (2017). Determinants of Financial Well-Being among Public Employees in Putrajaya, Malaysia. 25(3), 1241-1260.

OECD. (2018). OECD / INFE Toolkit For Measuring Financial Literacy AND. May.

OJK. (2017). Strategi Nasional Literasi Keuangan Indonesia ( Revisit 2017).

OJK. (2019). Peraturan Otoritas Jasa Keuangan Nomor 76 /POJK.07/2016. Journal of Chemical Information and Modeling, 53(9), 1689-1699.

https://doi.org/10.1017/CBO9781107415324.0 04

Perwito. (2011). Pengaruh Analisis Faktor Fundamental Terhadap Return Saham Pendahuluan. ILmu Manajemen \& Bisnis, 2(2), 85-95.

https://doi.org/https://doi.org/10.17509/jimb.v2 i2.13089

Pradikasari, E., \& Isbanah, Y. (2018). Pengaruh Financial Literacy, Illusion of Control, Overconfidence, Risk Tolerance, dan Risk Perception Terhadap Keputusan Investasi Pada Mahasiswa di Kota Surabaya. Jurnal Ilmu Manajemen (JIM), 6(4), 424-434.

Putra, I. P. S., Ananingtiyas, H., Sari, D. R., Dewi, A. S., \& Silvy, M. (2016). experienced regret, dan risk tolerance pada pemilihan jenis investasi. https://doi.org/10.14414/jbb.v5i2.548

Rasuma Putri, N. M. D., \& Rahyuda, H. (2017). Pengaruh Tingkat Financial Literacy Dan Faktor Sosiodemografi Terhadap Perilaku Keputusan Investasi Individu. E-Jurnal Ekonomi Dan Bisnis Universitas Udayana, 9, 3407.

https://doi.org/10.24843/eeb.2017.v06.i09.p09
Tendelilin, E. 2010. Portofolio dan Investasi Teori dan Aplikasi. Yogyakarta: Kanisius.

Taft, M. K., Hosein, Z. Z., \& Mehrizi, S. M. T. (2013). The Relation between Financial Literacy, Financial Wellbeing and Financial Concerns. International Journal of Business and Management, 8(11), 63-75. https://doi.org/10.5539/ijbm.v8n11p63

Welly, Kardinal, \& Juwita. (2012). Analisis pengaruh literasi keuangan terhadap keputusan investasi di stie multi data palembang. MDP Palembang. eprints.mdp.ac.id

Williamson, T. (1998). An Analysis of Personal Financial Literacy Among College Students. 7(2), 107-128.

Zulbetti, R. et al. (2019) "Upaya Peningkatan Literasi Keuangan Pengurus BUMDES Melalui Pelatihan Keuangan di Kecamatan Cimaung Kabupaten Bandung. Vol 19, No 2 (2019), pp. 200-211. https://doi.org/10.30596/ekonomikawan.v19i2. 3824 